\title{
Notes
}

\section{The Guilty But Mentally Ill Verdict and Due Process}

The guilty but mentally ill (GBMI) verdict authorizes both a conventional criminal sanction and psychiatric treatment for a mentally ill defendant who sought to be found not guilty by reason of insanity (NGRI). This new verdict ostensibly permits society to offer compassion and rehabilitation to the offender, while condemning the crime and providing for state control over the offender for the period of the criminal sentence. ${ }^{1}$ Perhaps for these reasons, the GBMI verdict has attracted attention ${ }^{2}$ and generally has been well received. ${ }^{3}$

GBMI laws, however, lack protections normally associated with the exercise of state power of the type that the GBMI verdict authorizes. This Note argues that this verdict implicates several interests rooted in the First, Fourth, Fifth, Eighth, and Fourteenth Amendments, as well as in penumbral privacy rights. The Note identifies differential losses experienced by the GBMI inmate relative to persons convicted under the traditional guilty verdict, and proposes a less restrictive alternative that minimizes such losses while protecting state interests. The Note concludes that the additional burdens on the person convicted under a GBMI law are constitutionally impermissible under the due process clauses of the Fifth and Fourteenth Amendments.

\section{The GBMI Law}

GBMI statutes respond to concern and confusion surrounding the law

1. See Kaufman, The Insanity Plea on Trial, N.Y. Times, Aug. 8, 1982, § 6 (Magazine), at 16, 20 (observing that GBMI verdict-permits expression of disapproval and mercy for offenders with diminished mental capacities).

2. See, e.g., Beach, Picking Between Mad and Bad, TIME, Oct. 12, 1981, at 68; Nesson, A Needed Verdict: Guilty But Insane, N.Y. Times, July 1, 1982, at A19, col. 2.

3. Several states, beginning with Michigan, have adopted some form of GBMI verdict. See MICH. COMP. LAWS ANN. § 768.36 (1982); ILL. REV. STAT. ch. $38, \S \S 113-4,-5,115-1$ to -4, -6, 1005-2-6 (1981); IND. CODE \& 35-5-2 (1979 \& Supp. 1981); see also Summary \& Analysis: The Insanity Defense, 6 MENTAL DISABILITY L. REP. 218, 219 (1982) (noting recent state interest in GBMI approach). A federal GBMI law has been proposed. See ATTORNEY GENERAL's TASK FORCE ON VIOLENT CRIME: FINAL REPORT 54 (1981) (recommendation 39, proposing Illinois law as model). 
relating to the mentally ill offender. This Part of the Note outlines the structure of a typical GBMI law, its legal and political context, and the reactions to such a law.

\section{A. Provisions in the GBMI Law}

A GBMI verdict may be returned if a criminal defendant raises the insanity defense and the trial fact-finder concludes that the defendant (i) committed the offense charged, (ii) was mentally ill ${ }^{5}$ at the time of the offense, and (iii) was not legally insane ${ }^{6}$ at the time of the offense."

The GBMI verdict confers broad sentencing power. GBMI-convicted offenders may receive a sentence equivalent to that possible under the traditional guilty verdict. ${ }^{8}$ Such offenders are also subject to additional controls: ${ }^{\ominus}$ They can be required by prison authorities to undergo psychiat-

4. Concern over the insanity defense has been a central issue. The assassination attempt against President Reagan and the subsequent insanity defense presented by accused assailant John Hinckley heightened national attention to mental health issues in criminal law. See, e.g., Taylor, Hinckley Case and Suspects' Rights, N.Y. Times, Feb. 25, 1982, at A24, col. 1. Hinckley's acquittal by reason of insanity produced a storm of commentary and protest from the public, the press, and government officials. See, e.g., Cohn, The Hinckley Travesty, N.Y. Times, June 27, 1982, at E21, col. 1 (decrying Hinckley insanity acquittal); Ostrow, Hinckley Verdict Ignites Outrage, Hartford Courant, June 23, 1982, at 1, col. 1 (reporting public and official anger); Roberts, High U.S. Officials Express Outrage, Asking for New Law on Insanity Plea, N.Y. Times, June 23, 1982, at B6, col. 1 (U.S. Attorney General calls for reform of insanity defense, and several legislators approve GBMI verdict).

5. Mental illness is defined in Michigan, for example, to be "a substantial disorder of thought or mood which significantly impairs judgment, behavior, capacity to recognize reality, or ability to cope with the ordinary demands of life." MICH. COMP. LAWS ANN. $\$ 330.2001$ (a)(3) (1980). For purposes of the GBMI law, Illinois defines mental illness as "a substantial disorder of thought, mood, or behavior which afflicted a person at the time of the commission of the offense and which impaired that person's judgment, but not to the extent that he is [sic] unable to appreciate the wrongfulness of his behavior or is [sic] unable to conform his conduct to the requirements of law." ILL. REV. STAT. ch. 38, $\S$ 6-2(d) (1981).

6. See Model Penal Code $\$ 4.01$ (1) (Proposed Oflicial Draft 1962) ("A person is not responsible for criminal conduct if at the time of such conduct as a result of mental disease or defect he lacks substantial capacity either to appreciate the criminality [wrongfulness] of his conduct or to conform his conduct to the requirements of law."). With slight alterations, this formulation governs in most jurisdictions. Kaufman, supra note 1 , at 18.

7. MiCH. COMP. LAWS ANN. § 768.36(1) (1982); ILL. REV. STAT. ch. 38, § 115-3(c) (1981). Although this Note uses the Michigan and Illinois laws as principal statutory sources, it addresses issues generally raised by the GBMI approach.

8. See, e.g., MICH. COMP. LAWS ANN. $\$ 768.36(3)$ (1982) (court may impose any sentence upon defendant that could be imposed upon defendant convicted of same offense without finding of mental illness); ILL. REV. STAT. ch. 38, \& 1005-2-6(a) (1981) (same).

9. The principle of diminished capacity suggests that the presence of a mental illness of the sort contemplated by the GBMI law should work to reduce, rather than increase, criminal liability. See $A$. GOLDSTEIN, THE INSANITY DEFENSE 194-202 (1967) (discussing crime grade reduction under diminished capacity principle). Where a specific-intent crime has been charged, the diminished capacity concept allows a court to find a mentally impaired offender guilty of a less serious offense, one requiring only general mens rea. See, e.g., People v. Gorshen, 51 Cal. 2d 716, 336 P.2d 492 (1959); People v. Wells, 33 Cal. 2d 330, 202 P.2d 53 (1949). But see CAL. Penal CODE § 28(b) (West 1970 \& Supp. 1982) (abolishing defense of diminished capacity). The Model Penal Code would allow admission of evidence of mental illness whenever relevant to the existence of a state of mind required for an offense, without limitation to specific intent crimes. MODEL PENAL CODE $\S 4.02$ (1) (Proposed Official Draft 1962). 


\section{Guilty But Mentally Ill}

ric evaluations ${ }^{10}$ and treatment. ${ }^{11}$ Further, if they qualify for probation or conditional release, the court or parole authority is obligated, under certain circumstances, to order a compulsory treatment regime as a condition of release. ${ }^{12}$

\section{B. Context}

The twin components of the GBMI verdict-confinement of the mentally-ill offender and court-ordered psychiatric treatment-respond to doubts concerning the function and intelligibility of the insanity defense. ${ }^{13}$ This defense has been the subject of a great deal of legal debate and criticism, including calls for its abolition. ${ }^{14}$

If the GBMI verdict is viewed as an alternative to an insanity acquittal, ${ }^{25}$ its incarceration component addresses public concerns about crime

10. See, e.g., MICH. COMP. LAWS ANN. § 768.36(3) (1982) (requiring evaluation following incarceration); ILL. REV. STAT. ch. 38, § 1005-2-6(b) (1981) (mandating periodic inquiry and examination concerning nature, extent, continuance, and treatment of defendant's mental illness).

11. MICH. COMP. LAWS ANN. $\S 768.36(3)$ (1982) (defendant shall be given "such treatment as is psychiatrically indicated for his mental illness or retardation"); ILL. REV. STAT. ch. 38, § 1005-2-6(b) (1981) ("The Department of Corrections shall provide such psychiatric, psychological, or other counseling and treatment for the defendant as it determines necessary."). See generally Note, Conditioning and Other Technologies Used to 'Treat?' 'Rehabilitate?' 'Demolish?' Prisoners and Mental Patients, 45 S. CAL. L. REV. 616, 619-33 (1972) (providing survey of types of mental therapies).

12. See, e.g., MICH. COMP. LAWS ANN. \$ 768.36(3) (1982) ("treatment shall, upon recommendation of the treating facility, be made a condition of parole"); id. $\S 768.36(4)$ ("[T]rial judge, upon recommendation of the center for forensic psychiatry, shall make treatment a condition of probation."); ILL. REV. STAT. ch., 38 \& 1005-2-6(e)(1) (1981) (GBMI inmate "placed on probation or sentenced to a term of periodic imprisonment or a period of conditional discharge shall be required to submit to a course of mental treatment prescribed by the sentencing court").

13. See, e.g., C. Black, Capital Punishment: The INevitability of CapRice aNd Mistake 62 (2d ed. 1981) ("W]e cannot state these [insanity defense] criteria in any understandable form, in any form satisfying to the relevant specialists or comprehensible to either judge or jury, despite repeated and earnest trials."); see also J. MACDONALD, PSYCHIATRY AND THE CRIMINAL 83-85 (3d ed. 1976) (noting public dissatisfaction with insanity plea); supra pp. 475-76 (general displeasure with insanity defense); infra note 29 (confusion over insanity defense). See generally A. GOLDSTEIN, supra note 9, at 45-96 (discussing insanity defense standards); H. FINGARETTE, THE MEANING OF CRIMINAL INSANITY 123-253 (1972) (same). Even courts that create insanity defense standards are forced to acknowledge the difficulty in enunciating a clear and workable standard. See United States v. Brawner, 471 F.2d 969 (D.C. Cir. 1972) (en banc) (dropping D.C. Circuit's Durham rule and adopting American Law Institute standard).

14. See, e.g., NEW YORK DEP'T OF MENTAL HYGIENE, THE INSANITY DEFENSE IN NEW YORK 131-44 (1978); Goldstein \& Katz, Abolish the "Insanity Defense"-Why Not?, 72 YaLE L.J. 853 (1963); Szasz, The Insanity Plea and the Insanity Verdict, 40 TEMP. L.Q. 271, 281-82 (1967); U.S. Moves to Curb Insanity Defense, N.Y. Times, July 20, 1982, at A18, col. 3; New U.S. Insanity Law Urged, N.Y. Times, June 27, 1982, at 26, col. 2; see also Bazelon, The Morality of the Criminal Law, 49 S. CAL. L. REV. 385, 397 (1976) (author "increasingly attracted to the view that the insanity defense should be abolished"). But see Chambers, Insanity Defense Backed by Panel, N.Y. Times, Apr. 7, 1983, at B9, col. 1 (National Commission on the Insanity Defense endorses retention of insanity defense).

15. While the GBMI verdict is not properly an alternative to the insanity acquittal, see infra pp. $479-80$, many apparently view it as potentially playing that role, see supra notes 1-2, 4; infra notes $19,21,22,27,30$. 
and safety ${ }^{16}$ and allays uncertainty about the accuracy of psychiatric prediction, ${ }^{17}$ efficacy of treatment, ${ }^{18}$ and premature release into the general population. ${ }^{19}$ This assurance of incarceration contrasts sharply with the vague and poorly understood effects of an insanity acquittal. ${ }^{20}$ In addition, and also in contrast to the insanity defense, the GBMI verdict creates a predetermined period for observation and treatment of the offender's mental illness. Some authorities view such treatment as an appropriate consequence of conviction and as a way of reducing recidivism. ${ }^{21}$ For similar reasons, some jurors have indicated a desire for the option offered by the GBMI verdict. ${ }^{22}$

16. See J. Garofalo, Public Opinion about Grime: The attitudes of Victims and NONVICTIMS IN SELECTED CITIES (1977) (concluding that public views crime as serious problem, perceives crime increases in recent years, and feels threatened by crime).

17. Numerous authorities and studies forcefully challenge the accuracy of psychiatric predictions in general and of predictions of dangerousness in particular. See, e.g., B. ENNIS \& R. EMERY, THE RIGHTS OF MENTAL PATIENTS 19-22 (1978); T. THORNBERRY \& J. JACOBY, THE CRIMINALLY IN. SANE: A COMMUNITY FOLLOW-UP ON MENTALLY ILL OFFENDERS 196-97 (1979); Cocozza \& Steadman, The Failure of Psychiatric Predictions of Dangerousness: Clear and Convincing Evidence, 29 RUTGers L. REV. 1084 (1976); Diamond, The Psychiatric Prediction of Dangerousness, 123 U. PA. L. REV. 439 (1974); Ennis \& Litwack, Psychiatry and the Presumption of Expertise: Flipping Coins in the Courtroom, 62 CALIF. L. REv. 693 (1974); Rosenhan, On Being Sane in Insane Places, 179 SCIENCE 250 (1973); Violence Termed Hard to Foretell, N.Y. Times, June 27, 1982, $\S 1$, at 25, col. 1.

18. See B. ENNIS \& R. EMERY, supra note 17, at 99 (no treatment has been demonstrated effective for types of mental disorders associated with dangerous or criminal behavior); sce also Note, supra note 11, at 620 (noting ineffectiveness of mental treatment).

19. The Michigan GBMI law was passed as a direct response to a court requirement that NGRI acquittees be released from mental incarceration on the same basis as persons civilly committed, People v. McQuillan, 392 Mich. 511, 547, 221 N.W.2d 569, 586 (1974), and to the widely reported recidivism of such released persons. See Robey, Guilty But Mentally III, 6 BULL. AM. ACAD. PSYCHlATRY \& L. 374, 375 (1978) (reviewing history of Michigan GBMI law). The Hinckley case has also generated substantial discussion about how an NGRI acquittee may be released before being "cured." See, e.g., Uncertainties Over Hinckley, N.Y. Times, Aug. 8, 1982, at E6, col. 5; Insanity Laws Seen as Hurting Society: Psychiatrists Say the Rights of Mental Patients Make It Hard to Confine Them, N.Y. Times, July 1, 1982, at A15, col. 1.

20. Whether a jury considering an NGRI defense should be told of its consequences remains a matter of disagreement among jurisdictions. Some jurisdictions require that the jury be informed, others prohibit it, and the rest leave the decision to the court. See Schwartz, Should Juries Be Informed of the Consequences of the Insanity Verdict?, 8 J. PSYCHIATRY \& L. 167 (1980). Even when a jury is informed of the consequences of an NGRI verdict, the jury has little basis for evaluating what the receiving mental institution will do with the acquittee. See supra notes 17,19 (discussing vagaries of psychiatric judgments); infra note 87 (same).

21. Cf. J. MACDONALD, supra note 13, at 75 (quoting then-Circuit-Judge Warren Burger suggesting "dropping the fiction that we call the "defense of insanity" "and treating mentally impaired offender after conviction); B. WOOTTON, CRIME AND THE CRIMINAL LAW 40, 79-80 (1963) (prevention of recidivism should be goal of criminal sanction; prison should become more like hospital). See generally S. GLUECK, LAW AND PSYCHIATRY 137-59 (1962) (discussing how deemphasis of state of mind in guilt adjudication may correlate with increase in treatment while incarcerated); H.L.A. HART, PUNISHMENT AND RESPONSIBILITY 193-209 (1968) (same).

22. See R. SIMON, THE JURY AND THE DEFENSE OF INSANITY 178 (1967) (part of jurors' criticism of verdict choice stemmed from desire to commit defendant to institution that both punished and treated); Kaufman, supra note 1, at 19 (jurors in Hinckley case would have liked to have had GBMI option). 


\section{Reactions to the GBMI Law}

Michigan passed the first GBMI statute ${ }^{23}$ in 1975 , and the law has survived constitutional attack in the state supreme court on right-to-treatment $^{24}$ and equal protection ${ }^{28}$ grounds. Other courts have approved the GBMI concept, ${ }^{26}$ and a number of commentators have embraced the approach of the statute. ${ }^{27}$

Legal commentators and practitioners have mounted only limited challenges to the existing GBMI laws. A few opponents of such laws have advanced constitutional arguments that focus principally on the possibility of jury confusion or intentional misfinding. ${ }^{28}$ Those opponents argue that the difficulty in applying the insanity standard, ${ }^{29}$ coupled with the fear of releasing a "confessed" criminal into the community (or into psychiatric institutions that, in turn, may release him into the community), tempts juries to return a GBMI verdict for some of those defendants who, absent the GBMI law, might have received an insanity acquittal. ${ }^{30}$ Significant

23. MICH. COMP. LAWS ANN. $§ 768.36$ (1982).

24. In People v. McLeod, 407 Mich. 632, 288 N.W.2d 909 (1980), the Michigan Supreme Court rejected the trial court's finding that the possible unavailability of treatment mandated by the GBMI law violated either due process or the Eighth Amendment prohibition against cruel and unusual punishment. The court refused to invalidate the law on a yet undemonstrated inability of the state to provide treatment. The court stated that even if there were an actual failure to provide legislatively mandated treatment, "it does not follow that the statute is, for that reason, unconstitutional." 407 Mich. at 655, 288 N.W.2d at 915; see also People v. Sorna, 88 Mich. App. 351, 276 N.W.2d 892 (1979) (mandamus appropriate remedy when treatment mandated by GBMI law not provided).

25. The court summarily rejected an equal protection challenge, saying that "the classification of 'mentally ill' in this context [of criminally convicted persons] has none of the indicia of a suspect class." People v. McLeod, 407 Mich. at 663, 288 N.W.2d at 919 (footnote omitted). But see Note, Mental Illness: A Suspect Classification, 83 YALE L.J. 1237 (1974).

26. See, e.g., Gall v. Commonwealth, 607 S.W.2d 97, 113 (Ky. 1980) ("We commend [the GBMI] approach to our own General Assembly."); Novosel v. Helgemoe, 118 N.H. 115, 127, 384 A.2d 124, 131 (1978) (noting that other states have found GBMI law useful).

27. See, e.g., Robey, supra note 19; Comment, Insanity-Guilty But Mentally Ill-Diminished Capacity: An Aggregate Approach to Madness, 12 J. MAR. J. PRAC. \& PROC. 351 (1979); Comment, Guilty But Mentally Ill: An Historical and Constitutional Analysis, 53 J. URBAN L. 471 (1976); see also supra notes 1-4 (citing calls for GBMI law in wake of Hinckley acquittal); Watkins, Guilty But Mentally Ill: A Reasonable Compromise for Pennsylvania, 85 DICK. L. REV. 289 (1981) (GBMI verdict sensible solution to some of inconsistencies of insanity defense).

28. See Sherman, Guilty But Mentally Ill: A Retreat from the Insanity Defense, 7 AM. J.L. \& MED. 237 (1981); Note, The Constitutionality of Michigan's Guilty But Mentally III Verdict, 12 U. MiCH. J.L. REF. 188 (1978); cf. N.Y. Times, July 12, 1982, at A14, col. 3 (letter from law and psychiatry professor observing that GBMI verdict is another guilty verdict and increases chance of conviction, thus "hoodwinking" juries).

29. See S. RUBIN, PSYCHIATRY AND THE CRIMINAL LAW 59-60 (1965) (characterizing jury's task in insanity case as "mystifying"); supra note 13 (noting confusion surrounding insanity defense). Empirical evidence suggests that jurors are ill equipped to deal with legal rules or complex cases. See Arens, Granfield \& Susman, Jurors, Jury Charges and Insanity, in THE SOCIOLOGY OF PUNISHMENT AND CORRECTION 208, 224 (N. Johnston, L. Savitz \& M. Wolfgang eds. 1970) (experimental jurors "manifested startlingly low comprehension of the charge materials presented to them"); Hoffman \& Bradley, Jurors on Trial, 17 MO. L. REV. 235 (1952) (jurors disregard rules of law and have great difficulty remembering relevant facts); Hunter, Law in the Jury Room, 2 OHIO ST. L.J. 1 (1935) (jurors poor at applying rules to relevant issues).

30. Developments in the law afford the NGRI acquittee procedural protections that enhance the 
obstacles, however, block challenges to the law on the ground of jury "error."31

This Note does not question the jury's fact-finding competence. Rather, it assumes that defendants found GBMI will come from the class of defendants who would have been convicted under the traditional guilty verdict but for the GBMI law. ${ }^{32}$ The Note, therefore, examines the relatively greater loss to a defendant found GBMI rather than merely guilty.

\section{Due Process Under the GBMI Law}

A GBMI verdict exposes an offender to liberty deprivations greater than those faced by an offender who is not found mentally ill. The GBMI law bases this heightened exposure to liabilities on a finding made at trial that the defendant was mentally ill at the time of offense. To be constitutional, the offender's loss must be justified under a due process analysis. The Supreme Court has developed a balancing test to evaluate the adequacy of procedural safeguards. ${ }^{33}$ The test considers: (i) the individual's

chance of release once the illness reaches a stage not liable to civil commitment. See, e.g., Humphrey v. Cady, 405 U.S. 504 (1972) (prisoners entitled to civil commitment procedures after sentence expiration); Baxtrom v. Herold, 383 U.S. 107 (1966) (same); Bolton v. Harris, 395 F.2d 642 (D.C. Cir. 1968) (NGRI acquittees have right to procedures substantially like those of civil commitment); People v. McQuillan, 392 Mich. 511, 221 N.W.2d 569 (1974) (requiring application of civil commitment procedures to NGRI acquittees); see also German \& Singer, Punishing the Not Guilty: Hospitalization of Persons Acquitted by Reason of Insanity, 29 RUTGERS L. REV. 1011, 1013-35 (1976) (describing increasing legal parity between criminally convicted and other mentally ill persons). Such a release procedure is not available to the GBMI convict. Denial of an NGRI acquittal and the imposition of a GBMI conviction in its place, through jury error or abuse, therefore arguably violates due process and equal protection rights. Commentators making these arguments assume that juries will select GBMI recipients from the ranks of those who would otherwise be found NGRI. From the history of the Michigan statute, it is likely that the legislature was motivated by precisely this hope. See supra note 19 (sketching history of Michigan GBMI law). A recent study concluded, however, that defendants found GBMI in Michigan probably would have been found guilty in the absence of the GBMI law. See Project, Evaluating Michigan's Guilty But Mentally III Verdict: An Empirical Study, 16 U. MICH. J.L. REF. 77, 103 (1982).

31. First, jury deliberations are secret. See Clark v. United States, 289 U.S. 1, 12-13 (1933) (jury secrecy needed to protect free debate). Second, it is difficult to classify cases so as to permit comparisons of jury behavior with respect to similar sets of cases before and after the institution of the new verdict. Third, identification of meaningful patterns of jury behavior would require extensive data collection and analysis. Even though the type of jury behavior claimed by commentators may exist, the necessary demonstration may be hard to make conclusively, thereby reducing its effectiveness in challenging the constitutionality of a GBMI law. Cf. Project, supra note 30, at 80, 93, 101 (no appreciable change in number of NGRI acquittals in Michigan since GBMI law became effective).

32. The three findings required for a GBMI verdict, see supra p. 476, can only apply to a subset of those who would have been found guilty before the passage of a GBMI law, since members of the NGRI class are presumptively insane and thereby excluded from the GBMI class. Empirical data agree with this theoretical analysis. See Project, supra note 30, at 103.

33. See Mathews v. Eldridge, 424 U.S. 319,335 (1976) (stating three-part test); see also Youngberg v. Romeo, 102 S. Ct. 2452, 2461 (1982) (due process balances individual rights against demands of organized society). In a sense, the three-part due process test may understate the individual harms; some would contend that at least certain constitutional rights cannot be balanced against any state interest. See, e.g., United States v. Reidel, 402 U.S. 351, 359 (1971) (Harlan, J., concurring) (certain First Amendment rights outweigh any state objective); Konigsberg v. State Bar, 366 
interests implicated by the statute; (ii) the likelihood of erroneous denial of those interests, and the probable value of additional or alternative procedural safeguards; and (iii) the interests of the state in imposing treatment under the statute's procedures. This section analyzes the elements of the due process balance in the GBMI context.

\section{A. Individual's Interests and Differentially Greater Loss Under the GBMI Sanction}

The harms to which a GBMI verdict exposes an inmate involve losses raising constitutional concerns. ${ }^{34}$ Each of these losses is the differentially greater exposure borne by the GBMI inmate relative to one found merely guilty.

\section{Direct Liberty Loss Caused by the GBMI Verdict}

The GBMI sanction explicitly includes the sanction existing under the guilty verdict, as well as additional controls and therapies. ${ }^{35}$ These enhanced controls place additional burdens on the GBMI inmate. The Supreme Court has recognized an inmate's interest in avoiding the type of psychiatric treatment to which a GBMI inmate is exposed. ${ }^{36}$ While the state may have a right to make some intrusions as an incident of incarceration, ${ }^{37}$ the GBMI law might increase the frequency or severity of such

U.S. 36, 61 (1961) (Black, J., dissenting) (drafters of "Bill of Rights did all the 'balancing' that was to be done in [First Amendment] field").

34. While such loss claims are used here in a due process balancing, they have their own substantive constitutional foundations. In fact, one or more of the following sections in the text may form an independent constitutional argument against the GBMI law. The evaluation of such constitutional claims, however, is complicated both by the novelty of the context in which these constitutional principles must be applied and by the state's prerogative to deprive prisoners of certain rights possessed by free citizens. See infra note 37 (discussing prisoner rights doctrine). The difficulty of assessing whether a given right (even though constitutionally based) is constitutionally protected in the prison context argues for a due process balancing analysis. $C$. G. CALABRESI, A COMMON LAW FOR AN AGE OF STATUTES 180-81 (1982) (discussing constitutional absolutist and balancing approaches).

35. See supra pp. 476-77 (outlining provisions of GBMI statutes).

36. In Vitek v. Jones, 445 U.S. $480,493-94$ (1980), the Court said that a "criminal conviction and sentence of imprisonment extinguish an individual's right to freedom from confinement for the term of his sentence, but they do not authorize the State to classify him as mentally ill and to subject him to involuntary psychiatric treatment without affording him additional due process protections." The Court also classified "[c]ompelled treatment in the form of mandatory behavior modification programs" as an appropriate matter for judicial attention. Id. at 492; see also Rennie v. Klein, 462 F. Supp. 1131, 1147 (D.N.J. 1978) (in mental health context, change from confinement to confinement plus forced medication involves major change in conditions); $j d$. at 1144 (incarceration alone not basis for forced medication); Liles v. Ward, 424 F. Supp. 675 (S.D.N.Y. 1976) (transfer, without commitment hearings, of prisoners from prison to state hospital used to treat prisoners who are mentally ill may violate due process and equal protection).

37. For example, while a prison may well have legitimate administrative grounds to examine its inmates-either periodically or on the basis of need-such examinations must reasonably be limited to the actual administrative requirements. The doctrine of Coffin v. Reichard allows such examination, but limits it to the actual requirements of the orderly operation of the institution. 143 F.2d 443, 445 (6th Cir. 1944) (prisoners retain rights unless loss necessarily implied by incarceration or right statu- 
intrusions beyond the permissible limits. Also, even if the GBMI convict is permitted to leave prison on probation or conditional release, the statute requires controls beyond those imposed on an ordinary probationer. ${ }^{\mathbf{3 8}}$

\section{Stigma}

In addition to explicit controls, the GBMI inmate suffers other substantial consequences. One of these is the stigma of being labeled mentally ill in an official and public proceeding. ${ }^{39}$ The Supreme Court has recognized the harmful effects of such stigmatization. ${ }^{\mathbf{4}}$ Here, the conjunction of mental illness with criminal behavior intensifies the onus. Although the verdict is "guilty but mentally ill," the effective message is "guilty and mentally ill." 41

\section{Systemic Bias}

In the criminal context, the "mentally ill" label may influence those who control the life of the GBMI inmate. For example, officials may wish to avoid releasing a person declared mentally ill and guilty, since the public may hold their institution responsible if the released person is subsequently accused criminally. ${ }^{42}$ In addition, decisionmakers may interpret

torily removed), cert. denied, 325 U.S. 887 (1945).

38. See supra p. 477 (GBMI verdict may add requirement of psychiatric evaluation and treatment as condition of release).

39. See In re Ballay, 482 F.2d 648, 650 (D.C. Cir. 1973) ("[W]e cannot help but recognize the stigma which unfortunately still accompanies a finding of mental illness."). One might claim that the legislature intended the public finding of mental illness to mitigate the hardships of criminal conviction, not to harm further. Such a legislative intent, however, cannot withstand a showing of an unconstitutional result. For example, legislatures undoubtedly mean to help persons through laws providing for involuntary commitment and treatment. Nevertheless, courts have voided such laws on constitutional grounds. See infra note 62 (citing cases in which compulsory treatment declared unconstitutional); see also Trop v. Dulles, 356 U.S. 86, 95 (1958) (legislative classification of statute not conclusive in determining if constitutional violation exists); H. PACKER, THE LIMITS OF THE CRIMINAL SANCTION 32 (1968) (basing results on party's intentions deprives distinction of "pretense of objectivity").

40. See Vitek v. Jones, 445 U.S. 480, 488 (1980) (stigmatizing effect of transfer of prisoner to mental health facility); see also Addington v. Texas, 441 U.S. 418, 425-26 (1979) (involuntary commitment to mental hospital "can engender adverse social consequences to the individual" and whether "we label this phenomenon 'stigma' or choose to call it something else . . . it can have a very signifcant impact on the individual").

41. See Taney, Psychiatry and the Prison System, 27 J. Forensic SCl. 385, 391 (1982) (mentally-ill criminal offenders are "doubly cursed"); German \& Singer, supra note 30, at 1011-12 (same). Society may associate the combination with criminal insanity and dangerousness.

42. See B. ENNIS \& R. EMERY, supra note 17, at 21 (noting psychiatrists' overprediction of dangerouness to avoid embarrassment and lawsuits); supra note 19 (noting public outcry following $M c Q u i l l a n$ releases and recidivism). Alan Dershowitz wrote: "The fact that errors in underestimating the possibilities of violence are more visible than errors of overestimating inclines the psychiatrist . . . to err on the side of confining rather than of releasing. His modus operandi becomes: When in doubt, don't let him out." Dershowitz, On Preventive Detention, N.Y. REV. BoOKS, Mar. 13, 1969, reprinted in A. GOLDSTEIN \& R. ORLAND, CRIMINAL PROCEDURE 473, 477 (1974). But cf. Bowers v. DeVito, 686 F.2d 616 (7th Cir. 1982) (Posner, J.) (finding state mental facility not liable under 42 
data on the inmate's progress to reinforce the preexisting label of "mentally ill." 43

These phenomena affect the GBMI defendant at several stages while in state control. First, the sentencing judge acts in the face of a jury's public declaration of the criminality and mental illness of the defendant. ${ }^{44}$ Second, state psychiatric personnel operate under the same notice of the defendant's trial label and therefore may be inclined to resolve doubts concerning the defendant's mental status in favor of greater control or more treatment. ${ }^{45}$ The incentives present in the decision to place the defendant in therapy also act to discourage the termination of such control once it has begun. ${ }^{46}$

\section{Privacy}

Constitutional "penumbras"47 protect certain realms of personal autonomy and conduct against state intrusion or control. Privacy interests exist with respect to bodily integrity, ${ }^{48}$ certain personal and family relationships, ${ }^{49}$ and behavior within the home. ${ }^{50}$ It would be anomalous if the law

U.S.C. $\S 1983$ for release of NGRI acquitted person who after release murdered plaintiffs decedent; court expressly reserved its view on tort liability).

43. Cf. Coffee, The Future of Sentencing Reform: Emerging Legal Issues in the Individualization of Justice, 73 MICH. L. REV. 1361, 1382 (1975) (noting theory that decisionmakers follow labels).

44. The judge is the official visibly responsible for protecting the public from a person perceived by many-rightly or not-as dangerous. The judge's inclination to respond to actual or imagined pressure is enhanced by the available sentencing authority, which includes the authority a judge has under a guilty verdict, and by the rationalization that treatment provided during incarceration will benefit the defendant.

45. While the decision not to treat ordinarily would mean the GBMI inmate's return to the regular prison population rather than into the general public, the psychiatrist may nonetheless resolve any doubt in favor of continued restraint, because the psychiatrist may be held accountable if the inmate is later disruptive in prison. Subsequent release into society-at-large, followed by recidivism, could also be traced back to therapeutic opportunities not exploited by the doctors of record. $C f$. $B$. ENNIS \& R. EMERY, supra note 17, at 21 (mental health professionals apt to overpredict dangerousness).

46. See German \& Singer, supra note 30 , at 1061.

47. See Griswold v. Connecticut, 381 U.S. 479, 484 (1965) (Douglas, J.) ("specific guarantees in the Bill of Rights have penumbras"); Olmstead v. United States, 277 U.S. 438, 469 (1928) (Holmes, J., dissenting) (referring to penumbras of constitutional amendments).

48. See Runnels v. Rosendale, 499 F.2d 733, 735 (9th Cir. 1974) (recognizing prisoner's "constitutionally protected right to be secure in the privacy of one's own body against invasion by the state except where necessary to support a compelling state interest"). But cf. Ingraham v. Wright, 430 U.S. 651 (1977) (allowing corporal punishment of school children); Schmerber v. California, 384 U.S. 757 (1966) (permitting drawing of blood from drunk-driving suspect). See generally Roe v. Wade, 410 U.S. 113, 154 (1973) ("right of personal privacy includes the abortion decision"); Union Pac. R.R. v. Botsford, 141 U.S. 250, $251-52$ (1891) (no right more sacred than right to possession and control of own person).

49. See, e.g., Loving v. Virginia, 388 U.S. 1 (1967) (marriage); Griswold v. Connecticut, 381 U.S. 479 (1965) (contraception); Prince v. Massachusetts, 321 U.S. 158 (1944) (family relationships); Skinner v. Oklahoma, 316 U.S. 535 (1942) (procreation); Pierce v. Society of Sisters, 268 U.S. 510 (1925) (child rearing). But see Doe v. Commonwealth's Attorney, 403 F. Supp. 1199 (E.D. Va. 1975) (upholding statute prohibiting private, consensual sodomy), aff'd mem., 425 U.S. 901 (1976).

50. See Stanley v. Georgia, 394 U.S. 557 (1969) (protecting obscene materials in home). 
viewed the body and home as private sanctuaries, but denied this protection to the even more personal sanctuary of the mind. ${ }^{51}$

The forms of "treatment" that the state might impose under a GBMI verdict may well include those that will alter mental function or memory. ${ }^{52}$ Attempts by the state to explore or modify the thoughts or thought processes of persons against their wills may conflict with privacy interests recognized and protected by the Constitution..$^{53}$

\section{Cruel and Unusual Punishment}

The Eighth Amendment proscribes the infliction of "cruel and unusual punishments." ${ }^{24}$ When imposed as criminal punishment, physical or psychological intrusions that inflict bodily harm, ${ }^{\text {sB }}$ or painful or terrorizing

51. See Huguez v. United States, 406 F.2d 366, 382 n.84 (9th Cir. 1968) ("[N]or are the intimate internal areas of the physical habitation of mind and soul any less deserving of precious preservation from unwarranted and forcible intrusion than are the intimate internal areas of the physical habitation of wife and family."). While civil commitment raises similar questions, its viability offers little support for the GBMI laws because the interests involved are different (removing an imminently dangerous person from the public), and because the state has only a very limited right to impose therapy on even the committed patient. See infra note 62 (summarizing restrictions on compulsory treatment of mental patients).

52. For example, psychotropic drugs are widely used in the treatment of mental patients, see, e.g., T. DETRE \& H. JARECKI, MODERN PSYChIATRIC TREATMENT 17-18 (1971); Kaufman, The Violation of Psychiatric Standards of Care in Prisons, 137 AM. J. PSYCHIATRY 566, 568 (1980); Note, supra note 11, at 623-26, and can dramatically alter mental processes, see, e.g., Shapiro, Legislating the Control of Behavior Control: Autonomy and the Coercive Use of Organic Therapies, 47 S. CAl. L. REV. 237 (1974); Note, supra note 11.

53. See Olmstead v. United States, 277 U.S. 438, 478 (1928) (Brandeis, J., dissenting) (makers of Constitution "sought to protect Americans in their beliefs, their thoughts, their emotions and their sensations. They conferred, as against the Government, the right to be left alone-the most comprehensive of rights . . . ."); see also United States v. Reidel, 402 U.S. 351, 359-60 (Harlan, J., concurring) (referring to "privacy of thought" and freedom of "inner life"); Rennie v. Klein, 462 F. Supp. 1131,1144 (D.N.J. 1978) (right of privacy protects mental processes from governmental interference); Kaimowitz v. Michigan Dep't of Mental Health (Mich. Cir. Ct. 1973), reprinted in A. BRooks, LAW, PSYCHIATRY AND THE MENTAL HEALTH SYSTEM 902, 919-20 (1974) "'There is no privacy more deserving of constitutional protection than that of one's mind. . . . If one is not protected in his thoughts, behavior, personality and identity, then the right of privacy becomes meaningless."). Even in "talk" therapies (for example, psychotherapy), state involvement in the process raises "captive audience" and privacy questions. For a discussion of the "captive audience" doctrine and its vitality, see Emerson, The Affirmative Side of the First Amendment, 15 GA. L. REV. 795, 833-34 (1981).

54. U.S. CONST. amend. VIII.

55. For example, widely used psychotropic drugs have various unpleasant and harmful side effects. Tardive dyskinesia, a common side effect, has been diagnosed following treatment with all currently approved antipsychotic medications. Kessler \& Waletzky, Clinical Use of the Antipsychotics, 138 AM. J. PSYCHIATRY 202, 205 (1981). The syndrome can be irreversible and can include tremors and loss of control as in Parkinson's disease. See 5 AMERICAN HANDBOOK OF PSYCHIATRY 262-63 (D. Freedman \& J. Dyrud 2d ed. 1975) (describing symptoms including uncontrollable movements and contractions of body); see also Jeste \& Wyatt, Changing Epidemiology of Tardive Dykinesia: An Overview, 138 AM. J. PSYCHIATRY 297, 297 (1981) (frequency of tardive dyskinesia high among patients treated with antipsychotic drugs, and can occur in all age groups).

Widely used antipsychotic drugs can cause numerous other unwanted side effects, including weakness, drowsiness, increased tension, tremors, hangover, visual hallucinations, anxiety, agitation, dry mouth, unpleasant taste, constipation, diarrhea, urinary retention, convulsions, confusion, hypertension, aggravation of glaucoma, vomiting, anorexia, gastric discomfort, impaired performance and judg- 
experiences $^{68}$ of the sort possible in psychiatric treatment, would justify an Eighth Amendment inquiry. ${ }^{67}$

If the harm, pain, or terror is an incidental effect of medical therapy, a finding of an Eighth Amendment violation is unlikely. ${ }^{58}$ The state, therefore, has a strong incentive to claim that psychiatric treatment is predicated on a finding of illness, rather than on the commission of a crime, and that the treatment imposed is proper medical therapy for the illness. ${ }^{58}$ The former claim may dispel the appearance that the pain or intrusion is being inflicted as punishment in response to the criminal act, and the latter may justify incidental pain or intrusion. ${ }^{60}$

The GBMI verdict, however, is processed through the criminal system: The issue of mental illness arises from the commission of a crime, and is tried in the criminal court. The source of control is a past event-the mental illness at the time of the crime-and the control authority extends

ment, long-term eye and skin effects, and decreased bone density. See 5 AMERICAN HANDBOOK OF PSYChIATRY, supra, at 441-513; HANDBOOK OF PSYChIATRY 427-63 (P. Solomon \& V. Patch 3d ed. 1975); Gammon, Neuroleptics and Decreased Bone Density in Women, 138 AM. J. PsYchIATRY 1517 (1981).

56. One exercise in aversion therapy carried out on both consenting and nonconsenting inmates in California involved injections of Succinylcholine (Anectine), which resulted in complete muscular paralysis including temporary respiratory arrest. Subjects likened it to dying, and some compared it to actual experiences in the past in which they had almost drowned. The majority described it as a "terrible, scary, experience." Shapiro, supra note 52, at 245-46 (quoting from report by participating physicians); see also Mackey v. Procunier, 477 F.2d 877, 878 (9th Cir. 1973) (Succinylcholine incidents could "raise serious constitutional questions respecting cruel and unusual punishment or impermissible tinkering with the mental processes" (footnotes omitted)); $c f$. A. BURGESS, A CLOCKWORK ORANGE (1962) (fictional account of aversion techniques). See generally B. ENNIS \& R. EMERY, supra note 17, at 98-99 (describing variety of abusive mental "therapies"); Singer, Psychological Studies of Punishment, 58 CALIF. L. REV. 405, 430-35 (1970) (discussion of aversion therapy and use in criminology).

57. See, e.g., Knecht v. Gillman, 488 F.2d 1136 (8th Cir. 1973) (aversion therapy involving drug apomorphine, which causes severe and extended vomiting, violates Eighth Amendment); Mackey v. Procunier, 477 F.2d 877 (9th Cir. 1973) (forced drugging for negative reaction suspect under Eighth Amendment). See generally Trop v. Dulles, 356 U.S. 86, 100 (1958) (Warren, C.J.) (techniques outside bounds of traditional penalties constitutionally suspect).

58. Even purported medical therapies, however, may violate the Eighth Amendment. See, e.g., Knecht v. Gillman, 488 F.2d 1136, 1139 (8th Cir. 1973) ("mere characterizaton of an act as 'treatment' does not insulate it from eighth amendment scrutiny"); Souder v. McGuire, 423 F. Supp. 830, 832 (M.D. Pa. 1976) ("involuntary administration of drugs which have a painful or frightening effect can amount to cruel and unusual punishment").

59. The sine qua non of treatment is a current illness. See, e.g., Rogers v. Okin, 634 F.2d 650, 657 (1st Cir. 1980) (involuntary medical patients may not be forcibly medicated solely for treatment purposes absent finding of incompetency), affg in relevant part Rogers v. Okin, $478 \mathrm{~F}$. Supp. 1342 (D. Mass. 1979), vacated and remanded sub nom. Mills v. Rogers, 102 S. Ct. 2442 (1982) (remand in light of new state case law development); Davis v. Hubbard, 506 F. Supp. 915 (N.D. Ohio 1980) (no legitimate interest justifies state's administration of psychotropic drugs absent informed consent of competent patient unless patient presents danger to himself or others); see also People v. McQuillan, 392 Mich. 511, 221 N.W.2d 569 (1974) (requiring current findings to justify the continued incarceration of NGRI acquittees held in state mental hospitals).

60. See generally Coleman \& Solomon, Parens Patriae "Treatment": Punishment in Disguise, 3 HASTINGS CONST. L.Q. 345, 353-54 (1976) ("treatment" label commonly used to justify harms to subject); Wilkins, Putting "Treatment" on Trial, 5 HASTINGs CENTER REP. 35, 36, 39 (Feb. 1975) (same). 
into the future without regard to the inmate's current status. These qualities are characteristic of the criminal sanction. ${ }^{61}$

As a result, in the GBMI context the protections normally associated with involuntary psychiatric treatment are stripped away. Medical treatment may be imposed on a noncriminal, involuntary recipient only in rare and extreme situations and after current process. ${ }^{62}$ If the state abrogates such procedures by asserting its police power throught the criminal law, ${ }^{\text {es }}$ the resulting exercise of control over a prisoner should be liable to Eighth Amendment scrutiny. ${ }^{64}$ Use of the criminal law to exercise state control on the basis of mental illness probably could not withstand such examination. ${ }^{65}$

\section{Expression and Belief}

Psychiatric treatment attempts to modify the subject's thoughts or mental processes. ${ }^{86}$ This directly raises questions of First Amendment

61. Herbert Packer distinguishes punishment from treatment by the presence of two indicia: (i) the regime imposed is based on a past event, as opposed to treatment's use of current status; and (ii) it is imposed for the benefit of society rather than for the recipient. H. PACKER, supra note 39, at 26-27. Under Packer's definition, the "treatment" of the GBMI verdict could be labeled punishment. See also Coleman \& Solomon, supra note 60, at 354 (parens patriae treatment should be viewed as punishment); Wilkins, supra note 60 , at 36 (treatment based on current state, punishment on past event).

62. See, e.g., Rennie v. Klein, 653 F.2d 836 (3d Cir. 1981) (forced medication only justifiable under state police power or parens patriae power; noting that many jurisdictions have requirement of least restrictive treatment), vacated and remanded mem., 102 S. Ct. 3506 (1982) (remand for consideration under Youngberg v. Romeo, 102 S. Ct. 2452 (1982), which found right of involuntarily committed mentally retarded person to be free from bodily restraints); Rogers v. Okin, 634 F.2d 650 (1st Cir. 1980) (involuntary medical patients may not be forcibly medicated solely for treatment purposes absent finding of incompetency); Scott v. Plante, 532 F.2d 939, 946-47 (3d Cir. 1976) (absent emergency, nonconsensual medical treatment violates Constitution and tort law); Rhoden, The Right to Refuse Psychotropic Drugs, 15 HARV. C.R.-C.L. L. REV. 363 (1980); Schwartz, In the Name of Treatment: Autonomy, Civil Commitment, and Right to Refuse Treatment, 50 NOTRE DAME LAW. 808 (1975); Comment, Advances in Mental Health: A Case for the Right to Refuse Treatment, 48 TEMP. L.Q. 354 (1975); see also supra note 59 (noting restrictions on forced treatment of competent persons).

63. See Ludwig, Treatment and Sentencing: The Power of the Court, the Rights of the Defendant, and the Legal and Ethical Implications of Sentencing Alternatives, 8 CONTEMP. DRUS PROBS. 381, 384-85 (1979) (noting that criminal system may attempt to by-pass normal process required for imposition of treatment).

64. Cf. H. PACKER, supra note 39, at 54 ("Rehabilitation may be the most humane goal of punishment, but it is a goal of punishment so long as its invocation depends upon finding that an offense has been committed, and so long as its object is to prevent the commission of offenses."); Opton, Psychiatric Violence Against Prisoners: When Therapy is Punishment, 45 Miss. L.J. 605 (1974) (psychiatric treatments should be regulated as if punishments).

65. Mental illness itself may not be criminalized. Robinson v. California, 370 U.S. 660, 666 (1962) (law criminalizing mental illness "would doubtless be universally thought to be an infliction of cruel and unusual punishment"). If criminalization of mental illness is cruel and unusual, enhancement of a criminal sanction on the basis of mental illness is no less so. Mental illness, of course, is all that distinguishes the GBMI offender from other guilty defendants. See, e.g., MiCH. COMP. LAWS ANN. § 768.36(1) (1982); ILL. REV. STAT. ch. 38, § 115-4(j) (1981).

66. See Mackey v. Procunier, 477 F.2d 877, 878 (9th Cir. 1973) (forced drugging may be "impermissible tinkering with the mental processes"); SUBCOMM. ON CONSTITUTIONAL RIGHTS, SENATE COMM. ON THE JUDICIARY, 94TH CONG., 1ST SESS., INDIVIDUAL RIGHTS AND THE FEDERAL ROLE IN 
rights to hold and formulate thoughts and beliefs and to retain autonomy in mental activity. ${ }^{67}$ Scholars have identified protection of self-actualization and personal autonomy as a purpose of the First Amendment. ${ }^{68} \mathrm{~A}$ psychiatrically induced change of belief ${ }^{89}$ to bring an inmate within society's code of conduct ${ }^{70}$ seems perilously close to the "thought control" the First Amendment has been understood to prohibit. ${ }^{71}$

Even if the First Amendment's role is restricted, arguendo, to that of protecting public communication, and perhaps just political discourse ${ }^{\mathbf{7 2}}$ such protections may be at issue in the context of restructuring a prisoner's thinking. ${ }^{73}$ Further, First Amendment rights have received particu-

Behavior MOdification at iii (Subcomm. Print 1974) (Sen. Ervin's expression of concern over behavior technology's capacity to alter a person's "very personality and manner of thinking"); P. BERGER \& T. LUCKMAN, THE SOCIAL CONSTRUCTION OF REALITY 112-13 (1966) ("Therapy entails the application of conceptual machinery to ensure that actual or potential deviants stay within the institutionalized definitions of reality, or, in other words, to prevent the 'inhabitants' of a given universe from "emigrating." ").

67. See Wooley v. Maynard, 430 U.S. 705 (1977) (First Amendment prohibits state compulsion of expression of ideas); Abood v. Detroit Bd. of Educ., 431 U.S. 209, 235 (1974) ("II]n a free society one's beliefs should be shaped by his mind and his conscience rather than coerced by the State."); Baird v. State Bar, 401 U.S. 1 (1971) (denial of admission to bar based on applicant's refusal to take "loyalty oath" violates First Amendment as intrusion on belief); Kaimowitz v. Michigan Dep't of Mental Health (Mich. Cir. Ct. 1973), reprinted in A. BROOKS, supra note 53, at 917-18 ("A person's mental processes, the communication of ideas, and the generation of ideas, come within the ambit of the First Amendment. . . . Government has no power or right to control men's minds, thoughts, and expressions."); see also N. KITTRIE, THE RIGHT TO BE DIFFERENT 388-410 (1971) (discussing constitutional issues of personal autonomy); H. PACKER, supra note 39, at 57-58 (questioning "whether a theory of punishment that requires acquiescence in compelled personality change can ever be squared with long-cherished ideals of human autonomy").

68. Professor Thomas Emerson identifies four roles of the Amendment, one of which is individual self-fulfillment. T. EMERSON, THE SYSTEM OF FREEDOM OF EXPRESSION 6-7 (1970); Emerson, Toward a General Theory of the First Amendment, 72 YALE L.J. 877, 879-81 (1963); see also Shattuck \& Byers, An Egalitarian Interpretation of the First Amendment, 16 HARV. C.R.-C.L. L. REV. 377 (1981) (First Amendment protects individual autonomy as end in itself).

69. For example, drug or electroconvulsive treatments can cause loss of mental capacity; and this loss can be permanent. See T. DETRE \& H. JARECKI, supra note 52, at 635-55; see also Shapiro, supra note 52, at $262 \mathrm{n} .72$ ("[U]se of virtually any psychotropic drug is sufficiently intrusive to warrant first amendment scrutiny.").

70. Many authorities note that psychotherapy has a political and moral agenda. See, e.g., H. FingareTTE, supra note 13, at 97-120; S. HALlECK, THE POLITICS OF THERAPY 34-38 (1971); $M$. LEVINE, PSYCHIATRY AND ETHICS 19 (1972); M. NORTH, THE SECULAR PRIESTS 26 (1972); T. SZASZ, THE MANUFACTURE OF MADNESS 58 (1970).

71. See Stanley v. Georgia, 394 U.S. 557, 565-66 (1969) ("Our whole constitutional heritage rebels at the thought of giving government the power to control men's minds. . . . [I]t cannot constitutionally premise legislation on the desirability of controlling a person's private thoughts."); see also United States v. Reidel, 402 U.S. 351, 359 (1971) (Harlan, J., concurring) (condemning "programs of thought control" and suggesting that no state objective is adequate to justify such control).

72. See Meiklejohn, The First Amendment Is an Absolute, 1961 SUP. CT. REV. 245, 255 (First Amendment "protects the freedom of those activities of thought and communication by which we 'govern'").

73. Prisoners clearly may have disagreements with the social order, and may wish to bring these into the political arena. Of course, the First Amendment protects more than patently political activity, cven for prisoners. See, e.g., Pell v. Procunier, 417 U.S. 817 (1974) (prisoner retains First Amendment rights not inconsistent with status as prisoner or legitimate penological objectives); Coffin v. Reichard, 143 F.2d 443, 445 (6th Cir. 1944) (prisoners generally retain rights absent explicit removal or limitation necessarily implied by fact of incarceration), cert. denied, 325 U.S. 887 (1945); G. HAW- 
larly careful protection, ${ }^{74}$ even when the potential harm depends on a state official's discretionary act, or is otherwise speculative. ${ }^{75}$ In addition to the speech protections of the First Amendment, the free exercise clause $^{76}$ provides another line of support for the protection of thought and belief. ${ }^{77}$

\section{Bodily Restraint}

Freedom from bodily restraint is an interest that "survives criminal conviction and incarceration." 78 That is, even though the state may incarcerate a convicted person, while incarcerated that person has a constitutional interest in freedom from further restriction of his bodily autonomy. ${ }^{79}$ It is difficult meaningfully to distinguish the restraint of the physical pillory and shackles from that produced by the needle or the pill. ${ }^{80}$ Indeed, the physical restraints may be less harmful because they do not directly confine the mind. ${ }^{81}$

KINS, THE PRISON 135 (1976) (noting general acceptance of Coffin principle).

74. See, e.g., Brandenburg v. Ohio, 395 U.S. 444, 447 (1969) (state may not proscribe speech unless intended to and likely to produce imminent lawless action); West Virginia State Bd. of Educ. v. Barnette, 319 U.S. 624, 639 (1943) ("[F]reedoms of speech and of press, of assembly, and of worship ... are susceptible of restriction only to prevent grave and immediate danger to interests which the State may lawfully protect.").

75. See Dombrowski v. Pfister, 380 U.S. 479,487 (1965) (noting that exercise of First Amendment rights may be "chilled" by fear of prosecution). A similar chill must be present when an inmate knows that if he utters a "nonconforming" statement or behaves in an "unacceptable" manner, he may be subjected to some known, unpleasant therapy, or, perhaps worse, to an unknown one. See Shapiro, supra note 52, at 246 (observing that medical profession has demonstrated lack of self-control in using invasive therapies); supra notes 55-57 (describing harmful therapies). Further, compelled treatment can have irreversible effects, both with respect to the body, see supra note 55 (noting permanent harms possible from treatment), and by precluding the subject from post hoc remedies by eliminating the desire to resist, as by drugging. See generally Monaghan, First Amendment "Due Process", 83 HARV. L. REV. 518 (1970) (arguing that potential for First Amendment "chill" demands especially sensitive procedural devices); Note, The Void-for-Vagueness Doctrine in the Supreme Court, 109 U. PA. L. REV. 67 (1960) (analyzing Supreme Court's solicitude for First Amendment concerns, and its willingness to strike down laws encroaching, even speculatively, on rights protected by Amendment).

76. U.S. CONST. amend. I, cl. 1.

77. See Winters v. Miller, 446 F.2d 65 (2d Cir.) (upholding mental patient's free exercise claim against forced medication), cert. denied, 404 U.S. 985 (1971); see also 3 S. RUBIN, UNITED STATES PRISON LAW 105-08, 111-30 (1976) (First Amendment protects religious rights of prisoners). See generally T. EMERSON, supra note 68, at 21-41 (discussing origins and scope of First Amendment's protections of freedom of belief).

78. Youngberg v. Romeo, 102 S. Ct. 2452, 2458 (1982).

79. See id. at 2455 \& n.4 (asserting right of incarcerated mentally retarded person to be free of unnecessary physical restraints).

80. See Shapiro, supra note 52 (identifying debilitating and coercive effects of organic therapies); Note, supra note 11 (same).

81. Cf. To Althea from Prison, in THE POEMS OF RICHARd LOVELACE 70-71 (C.H. Wilkinson ed. 1925) ("Stone walls does not a prison make . . . ."). 


\section{B. Probability of Error}

The second component of the due process test focuses on the likelihood of an erroneous deprivation of rights under the challenged process. ${ }^{82}$ In the GBMI context, the finding of mental illness at the time of offense may be in error, and even if such a finding were accurate, it may authorize pointless treatment.

The vague definitions of the GBMI law ${ }^{83}$ make it difficult to identify mental illness reliably and consistently. Ambiguous and open-ended definitions fail to provide the coherent direction wanted when imposing criminal sanctions. ${ }^{84}$

The task of limiting the definition of mental illness seems quixotic in light of the elusive "insanity" definition. ${ }^{85}$ Moreover, were a workable standard available, the fact-finder still would face the difficulty of making a retrospective judgment about the defendant's mental state at the time of the offense. Limiting evidence to fragmentary and circumstantial information about a past state of mind, especially one as subtle as a mood disorder, obviously compounds the problem and increases the chance of error ${ }^{86}$ In addition, a lay jury or a technically unspecialized judge will witness a

82. For this recognizably probabilistic examination, the assumption of jury fact-finding perfection must be relaxed. This Note has assumed that juries correctly classify defendants as guilty, not guilty, NGRI, or GBMI. See supra pp. 479-80 (discussing jury role with respect to insanity defense and GBMI findings). In a due process balancing, however, the examination of the issue of probable error of the process explores empirical factors that may contribute to erroneous outcomes. See Mathews v. Eldridge, 424 U.S. 319, 343-47 (1976). The analysis will retain the assumption that any error would move an otherwise guilty defendant into the GBMI class.

83. See supra note 5 (stating Michigan and Illinois definitions of mental illness).

84. For a similar argument questioning a jury's ability to make fine distinctions about a defendant's state of mind, see J. MACDONALD, supra note 13, at 77 (diminished capacity criticized as requiring juries to "answer questions which are . . . by their nature unanswerable," because juries incapable of distinguishing fine degrees of mental impairment) (quoting S. BRACKEL \& R. ROCK, THE MENTALly DISABLED AND THE LAW (1971)). While definitions of "insanity" also are nearly impossible to apply with precision, the impairment is of such severity and rarity as to limit over-inclusive use. See H. Steadman, Invited Testimony Before Subcommittee on Criminal Law, Subcommittee on the Judiciary, United States Senate 2-3, 7 (July 14, 1982) (on file with Yale Law Journal) (observing infrequency of insanity defense cases and small fraction of acquittals in those cases); Stone, The Insanity Defense on Trial, 33 HARV. L. SCH. BULL. 15, 17 (1982) (noting data demonstrating rarity of insanity defenses). In the case of "mental illness," the described behavior is sufficiently commonplace to include virtually everyone at one time or another, and perhaps to include persons engaged in criminal acts on that basis alone. See J. MITFORD, KIND AND UsuAL PUNISHMENT 95-97 (1971) (noting view that criminality implies mental illness).

85. See supra notes 1-2,13-14, 29 (discussing problems with insanity defense).

86. Of course, one can claim that commonly used terms such as "mens rea" are equally unclear but are tolerated in the justice system. See, e.g., H.L.A. HART, supra note 21, at 90,91 n.2 (noting confusion over term). Use of such terms in crime definitions may be advanced as a form of precedent for vague terminology in law, particularly in this area. If, however, one were making a due process attack on the imprecision of the concept of mens rea, it would be appropriate to note the chance of error. Further, most people, including judges and jurors, have personal experience with such concepts as "intention," "volition," and "knowledge." Therefore, when instructed in the meaning of mens rea, they have at least a target concept to which they can attempt-however inaccurately-to match the state of mind of the accused. This usually cannot be said for "mental illness." 
"battle of the experts" in which technical and contradictory testimony often will be presented. ${ }^{87}$

Finally, using the trial fact-finder to make the mental illness determination creates the possibility of misfinding because the jury will have heard the defense argue that the defendant was insane. ${ }^{88}$ The probability of objectively erroneous results is even greater if one prevents the defendant from denying factfinder inferences made during an insanity defense. ${ }^{89}$

Another form of erroneous rights deprivation arises if the treatment is useless. ${ }^{90}$ Such error may occur when the mental illness found by the jury is not treatable or is episodic or otherwise not present during the period of incarceration under the GBMI verdict. Given the imprecision of psychiatric concepts, ${ }^{91}$ pressures to treat a GBMI inmate, ${ }^{82}$ and the prison's institutional interest in control of inmates, treatment may be given under a GBMI verdict even when it could not be justified on a current finding of therapeutic need..$^{93}$

\section{State Interests}

The state potentially has three interests relevant to the due process inquiry: (i) protection of persons; (ii) benefit to the GBMI inmate; and (iii) efficiency of prison administration. These interests prove to be insufficient to justify the losses inflicted on a GBMI inmate.

87. See Gallo, The Insanity of the Insanity Defense, 16 PROSECUTOR 6, 6 (1982) (quoting authority noting that defense psychiatrist always says defendant insane, prosecution psychiatrist always says sane); Szasz, Criminal Responsibility and Psychiatry, reprinted in LEGAL AND CRIMINAL PSYCHOLOGY 162 (H. Toch ed. 1961) (possible in virtually any case using psychiatric testimony to secure psychiatric testimony in opposition to it); see also R. SimoN, supra note 22, at 165 (experimental jurors not helped by psychiatric testimony); cf. supra note 17 (discussing inaccuracy of psychiatric prediction).

88. Cf. German \& Singer, supra note 30 , at 1034 (defendant prejudiced in attempt to demonstrate present sanity after arguing mental irresponsibility at time of crime, as trier of fact will have argument and details of crime uppermost in mind when deciding issue of present sanity).

89. Even assuming, arguendo, that the defendant should be estopped from disclaiming "admissions" made during an insanity defense, jury bias may result from information other than substantive, factual information about the defendant. For example, counsel's arguments or witness examinations can effectively impress jurors without dealing empirically with the defendant's status at all. Moreover, a clever prosecutor, knowing the effect of the GBMI law, might attempt to leave standing suggestions of "mental illness." To decide the issue of mental illness after such a one-sided proceeding clearly raises the issue of possible factual error.

90. See B. ENNIS \& R. EMERY, supra note 17, at 30 n.6 (some psychiatric treatment useless).

91. See supra notes $84-87$ (observing vagaries of psychiatric concepts).

92. See supra notes $42-43,45-46$ (discussing institutional forces to overpredict dangerousness of mentally ill persons).

93. See, e.g., Pena v. New York State Div. for Youth, 419 F. Supp. 203 (S.D.N.Y. 1976) (use of tranquilizing drugs to control inmates); Nelson v. Heyne, 355 F. Supp. 451 (N.D. Ind. 1972) (same); AMERICAN FRIENDS SERVICE COMM., STRUGGLE FOR JUSTICE 86 (1971) (describing manipulation of treatment for prison discipline); 2 S. RUBIN, UNITED STATES PRISON LAW 335 (1975) (expecting forced treatment for "security, discipline, or punishment, rather than treatment or rehabilitation"); Shapiro, supra note 52, at 245 n.10 (use of drugs for prisoner control). 


\section{Protection of Persons}

There are two categories of persons that ostensibly could be protected by a GBMI law: persons who may be in contact with the GBMI inmate during incarceration, and the general community after the GBMI convict's release from custody.

\section{a. Protection of Persons in the Place of Incarceration}

A claim that the therapeutic measures authorized by the GBMI verdict are necessary to protect persons in prison would fail for several reasons. First, a prisoner is in a highly controlled environment that limits his ability to engage in harmful conduct. In addition, the assumed mental illness may be unrelated to any predilection for criminal behavior. ${ }^{94}$ If the mental illness is acute or episodic, the patient may not manifest any symptoms throughout the period of custody. Even if the particular illness is both active and predisposing toward specific criminality, the inmate may not endanger other prisoners, ${ }^{85}$ and even if he did, mental treatment may not provide an effective protection for other inmates. ${ }^{96}$ Further, prisons are designed to control persons with high propensities for crime. It seems unreasonable, therefore, that any alleged potential for harm by GBMI inmates should be singled out under a rationale of protection of other inmates.

\section{b. Post-Release Protection of Persons in the Community}

The GBMI verdict might benefit society-at-large if treatment of an inmate's mental illness removed or reduced danger to the community. ${ }^{87}$ This

94. See State v. Krol, 68 N.J. 236, 247 n.2, 344 A.2d 289, 295 n.2 (1975) ("Empirical studies indicate that, as a group, persons suffering from mental illness are, at most, only slightly more likely to commit harmful acts than the general population."). Other commentators think that on average the mentally ill commit fewer crimes than the rest of the population. See T. SCHEFF, BEING MENTALLY ILL 72 \& n.17 (1966).

95. This would be the case, for example, if the criminal behavior in issue were spousal abuse or auto theft.

96. Sec, e.g., B. ENNIS \& R. EMERY, supra note 17, at 99 (no demonstrated effective treatment for dangerous criminal behavior); A. STONE, MENTAL HEALTH AND THE LAW: A SYSTEM IN TRANSITION 36 (1975) (dangerous personality disorders are not amenable to therapies, including psychotropic drugs).

97. While civil commitment laws serve this purpose, the conceded validity of those laws is not compelling precedent, without more, with respect to the GBMI case. An involuntary commitment standard of mere "mental illness" would be unreasonably low in light of the "massive curtailment of liberty" it entails. See Humphrey v. Cady, 405 U.S. 504, 509 (1972) (noting approvingly that Wisconsin's commitment law "conditions such confinement not solely on the medical judgment that the defendant is mentally ill and treatable, but also on the social and legal judgment that his potential for doing harm, to himself or to others, is great enough to justify such a massive curtailment of liberty" (footnote omitted)); see also A. STONE, supra note 96, at 25-40, 43-82 (discussing dangerousness and civil commitment standards); Developments in the Law-Civil Commitment of the Mentally IIl, 87 HARV. L. REV. 1190, 1203-05 (1974) (discussing state standards for involuntary commitment) [here- 
benefit, however, will accrue only if a causal connection exists between the mental illness and dangerousness, and if treatment "cures" that illness. The mental illness of the GBMI inmate, however, may be unrelated to the risk of recidivism. Indeed, as currently formulated, GBMI laws do not require that mental illness predispose the defendant to any particular behavior, including crime, either predictively or even with respect to the crime charged. ${ }^{98}$ Also, even an accurate finding with respect to the time of offense could be irrelevant by the time of the inmate's release. ${ }^{99}$

Assuming arguendo that the GBMI inmate's mental illness would cause recidivism, the ability to correct this by treatment is speculative, and even the ability to accurately diagnose the disorder is questionable. ${ }^{100}$ Even if one accepts the improbable hypothesis that a "cure" could be achieved during the term of incarceration of a GBMI inmate, persistence of that "cure" beyond the immediate period of treatment would be required to lend force to the state's interest in protecting the community. Most authorities, however, doubt that such "rehabilitation" will endure. ${ }^{101}$

inafter cited as Developments]. In addition, the state interest in removal from the general public accomplished by civil commitment is greater than the state interest in removal from (or forced drugging in) the already closely controlled prison environment, as occurs with the GBMI inmate. Finally, civil commitment does not bring with it the right to treat; the law today gives a substantial refusal right to the involuntarily committed. See supra note 62 .

98. See supra notes 5,7 (citing relevant Michigan and Illinois provisions). Though odd, this is not unique to GBMI laws. Wootton observes that a "guardianship order," under which a convicted offender in England might be treated, seemingly allows the same disconnection: "One curious feature of this provision is the fact that a hospital order can apparently be made on a diagnosis of mental disorder, even if the disorder has no connection with the offence." B. WOOTTON, supra note 21, at 62 n.3.

99. For example, the disorder may have been exogenous and confined to the time and circumstances proximate to the offense. The "thought or mood disorder" type of "mental illness" that the GBMI law uses might include simple depression, or disorders resulting from temporary hormonal imbalance; such "mental illness" may easily change over the period of incarceration. Also, neurotic disorders sometimes will disappear without treatment; such "spontaneous remission" is a recognized psychological phenomenon. See Lopez, The Crime of Criminal Sentencing Based on Rehabilitation, 11 GOLDEN GATE U.L. REV. 533, 556-57 (1981).

100. See Sherman, supra note 28 , at 252 (psychiatrists have difficulty agreeing on diagnosis even when patient interviewed at joint meeting) (citing Zubin, Classification of Behavior Disorders, 18 ANN. REV. PSYCHIATRY 373, 383 (1967)); supra note 17 (discussing inability of psychiatrists to make accurate predictions).

101. See AMERICAN FRIENDS SERVICE COMM., supra note 93, at 87 (various treatment strategies do not make any significant difference in future criminal behavior of inmates); B. BRAGINSKY, D. BRAGINSKY \& K. RING, METHODS OF MADNESS: THE MENTAL HOSPITAL AS LAST RESORT 179 (1969) ("statistics show clearly that even in the most active and up-to-date therapy centers in the world, the numbers of persons who have been successfully 'rehabilitated' is painfully small"); B. ENNIS \& R. EMERY, supra note 17, at 99 ("So-called sociopathic personalities, probably the most common diagnosis for persons who commit criminal acts, are apparently not treatable." (footnote omitted)); A. STONE, supra note 96, at 36 ("treatment success with personality disorders, particularly sociopaths, is quite limited" and, with respect to dangerous persons, psychiatric experts doubt efficacy of psychotherapy, psychotropic drugs, and behavior modification). Each of the major therapeutic techniques used in the treatment of mental conditions, see Note, supra note 11, at 619-33 (identifying major medical therapies), has been challenged as to lasting effect, including: (i) milieu therapy, see id. 


\section{Benefit to the GBMI Prisoner}

Benefitting the GBMI inmate is not a valid state objective because the state has no authority to force therapy on a competent member of society solely for that person's benefit. ${ }^{102}$ Under GBMI laws, no finding of incompetency is required, either at the time of offense or thereafter. ${ }^{103} \mathrm{In}$ deed, if incompetency could be shown, the state's parens patriae power would make the GBMI provisions for psychiatric control unnecessary. ${ }^{104}$

\section{Efficiency of Prison Administration}

The claim may be made that the labeling of mentally ill prisoners by the GBMI verdict is necessary for the efficient allocation of limited state resources. Under this rationale, knowing where psychiatric monitoring and care are needed would allow a more accurate and cost-effective delivery of services; similarly the close monitoring of GBMI inmates might reduce disruptions of prison operations. Such claims fail, however, because the finding of mental illness at the time of offense is probably a poor predictor of the need for continued monitoring and therapy throughout the

at 621-22, 630 (any benefit quickly lost after change of milieu); O'Connor v. Donaldson, 422 U.S. 563,569 (1975) ("'[M] hospital."); (ii) psychotherapy, see T. DETRE \& H. JARECKI, supra note 52, at 495, 520 (individual psychotherapy under fire in recent years as ineffective, particularly in treating mental illness); $D$. TENNOV, PSYCHOTHERAPY: THE HAZARDOUS CURE 62-102 (1975) (psychotherapy may produce deterioration in some patients); Epstein \& Vlok, Research on the Results of Psychotherapy: A Summary of Evidence, 138 AM. J. PSYCHIATRY 1027, 1033 (1981) (results "disheartening"); (iii) drug therapy, see Davis \& Cole, Antipsychotic Drugs, in 5 AMERICAN HANDBOOX OF PSYCHIATRY, supra note 55, at 454-56 (effectiveness of drugs to control symptoms of mental illness limited primarily to period of actual administration); (iv) behavior modification, see Note, supra note 11, at 630 (long-term effectiveness is function of post-treatment environment; if returned to same environment that previously reinforced unwanted behavior, very likely that same behavior will return); infra note 121 (behavior techniques ineffective when coerced); (v) convulsive therapies, see T. DETRE \& H. JARECKI, supra note 52, at 635-55 (produce symptom-reducing results in classes of patients while treatments ongoing, but little likelihood of long-term change after discontinuance).

102. See Rogers v. Okin, 634 F.2d 650, 657 (1st Cir. 1980) (sine qua non for use of parens patriac power to forcibly administer mind-affecting drugs is determination that subject lacks capacity to decide whether to take drugs), vacated and remanded sub nom. Mills v. Rogers, $102 \mathrm{~S}$. Ct. 2442 (1982); J.S. MILL, ON LIBERTY 135 (M. Warnock ed. 1962) ("He cannot rightfully be compelled to do or forbear because it will be better for him to do so, because it will make him happier, because, in the opinion of others, to do so would be wise, or even right."); Developments, supra note 97, at 121222 (incapacity of individual to make treatment decisions about self is threshold requirement for parens patriae control by state). See generally D. WEXLER, MENTAL HEALTH LAW 39-51 (1981) (discussing parens patriae control).

103. The law is plain in its support of the proposition that incompetency cannot be inferred from mental illness. See Winters v. Miller, 446 F.2d 65, 71 (2d Cir.) (deriding compulsory treatment of competent mental patient justified by doctors as "best" for patient), cert. denied, 404 U.S. 985 (1971). Involuntarily committed persons have broad rights to refuse treatment. See supra note 62 . These rights would be lost if incompetency were inferred from mental illness.

104. See generally Developments, supra note 97, at 1207-22 (discussing parens patriae authority when incompetency demonstrated). But see Coleman \& Solomon, supra note 60 (doubting validity of parens patriae concept). 
term of incarceration. ${ }^{105}$

\section{A Less Restrictive Alternative to Current GBMI Laws}

Where state action curtails fundamental rights, the government must have a compelling interest in that curtailment. ${ }^{108}$ Also, statutes that abridge fundamental rights must be narrowly drawn and necessary to achieve the stated end, using the least restrictive means available. ${ }^{107} \mathrm{Ac}-$ cordingly, and conforming with the error component of the due process test, which requires consideration of alternative procedures, ${ }^{108}$ this Note argues that a less restrictive alternative (LRA) to the GBMI law's procedures exists and that this alternative protects legitimate interests. The proposed alternative comprises two requirements: (i) that removal of any prisoner to a mental facility, whether or not within the prison, or imposition of any forced therapies may occur only after a finding of current need, ${ }^{109}$ and (ii) that any therapies that would have been available to a GBMI inmate be available on a voluntary basis to at least all inmates who presented an insanity defense. ${ }^{110}$ The suggested method, which eliminates the GBMI category, guarantees the availability of treatment for at least the would-be GBMI inmates, ${ }^{111}$ yet does not overwhelm the prison

105. See generally supra p. 491 (mental illness may not predispose inmate to misbehave in prison). Further, the mere fact of criminality may have been converted at trial into a psychiatric label, such as "sociopathic personality," and a GBMI inmate so labeled may not be relevantly different from any other inmate. See B. ENNIS \& R. EMERY, supra note 17, at 99; see also J. MITFORD, supra note 84, at 95-96 (1971) (discussing era when criminality taken to imply mental illness); cf. AMERICAN PSYCHIATRIC ASs'N, Dingnostic AND STATISTICAl MANUAl OF MENTAL Disorders 297-98 (3d ed. 1980) (defining "Isolated Explosive Disorder," which would classify many assaults as mental disorders per se).

106. See, e.g., Shapiro v. Thompson, 394 U.S. 618, 634 (1969) (requiring compelling state interest to penalize exercise of constitutional right in equal protection context); id. at 643-44 (Stewart, J.,

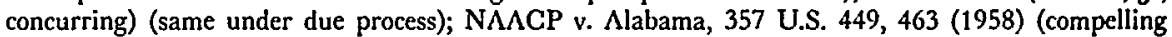
state interest required if statute infringes constitutional rights); Skinner v. Oklahoma, 316 U.S. 535, 541 (1942) (same).

107. See Dunn v. Blumstein, 405 U.S. $330,342-43$ (1972) (state cannot unnecessarily burden or restrict constitutionally protected activity and must choose "less restrictive means" where available).

108. See supra pp. 480-81 (indicating consideration of alternative procedures as part of duc process test).

109. Current need could be determined under the jurisdiction's civil commitment law, thercby treating all prisoners essentially like civilians for purposes of forced mental commitment or treatment. See A. STONE, supra note 96, at 25-82 (discussing civil commitment standards); Developments, supra note 97, at 1203-07 (same); supra notes 59, 62 (citing cases defining standards for compulsory treatment).

110. While a prisoner's right to medical care has been held to include psychiatric and psychological care, see Bowring v. Godwin, 551 F.2d 44 (4th Cir. 1977), the LRA's requirement of at least an offer of treatment to inmates who presented an insanity defense anticipates a "limited good" claim: The state wants to give GBMI inmates more care than is minimally due inmates generally; the state has limited treatment resources; and the GBMI verdict is needed to identify those whom the state wishes to receive those resources. Cf. Project, supra note 30, at 104-05 (as practical matter, GBMI prisoner no more likely to receive mental health treatment than prisoner with simple guilty verdict).

111. This term identifies inmates who would have been found GBMI in a system having that verdict. 
in its allocation of limited treatment resources. ${ }^{112}$ This Part considers the effect of the alternative procedure with respect to each of the topics discussed in the due process balancing.

\section{A. Individual Interests}

The proposed alternative eliminates the differential losses to a would-be GBMI inmate by removing the stigma of the verdict and all other exposures the GBMI law would have allowed. Since all inmates are exposed equally to the LRA process, the differentially greater losses to the wouldbe GBMI inmates are removed. ${ }^{113}$

\section{B. Probability of Error}

The proposed alternative is less likely to produce error in compelled hospitalization or treatment principally because it makes a finding of need based on current, directly obtained information about the inmate. Accuracy is further enhanced by the reduced impact of the criminal trial on the fact-finder and the greater technical expertise of the LRA fact-finder as compared to the trial judge or jury. Of course, the fact-finder that determines current need may be biased against the would-be GBMI inmate, just as the fact-finder in the GBMI system may be. ${ }^{114}$ A biased, counterfactual finding of current need under the LRA, however, is less likely than treatment erroneously given under the authority of a GBMI verdict. ${ }^{115}$

112. First, identification of the recipient class is administratively trivial. Second, relative to a GBMI system, there will be few additional inmates who will have to be offered the enhanced treatment. They will be those inmates who, following an insanity defense, would be found guilty and not mentally ill if they were tried in a GBMI system. This is a fraction of an already small number. See infra note 119 (there are very few NGRI pleas). Few, if any, of this class of inmates will accept treatment for a condition they have been found not to have. In effect, the treatment offer is relevant to just the class of would-be GBMI inmates. Further, since the treatment is voluntary, the net demand on the prison might be less than under a GBMI system.

113. In particular, since the authority to treat GBMI inmates forcibly is not present, the temptation for a prison to use the institutionally convenient approach of forced drugging is removed. See Souder v. McGuire, 423 F. Supp. 830 (M.D. Pa. 1976) (condemning practice of routine drugging of prisoners for control purposes); Pena v. New York State Div. for Youth, 419 F. Supp. 203 (S.D.N.Y. 1976) (rejecting drugging to control juvenile offenders); 2 S. RUBIN, supra note 93, at 335 ("it would be expected that the imposition of drugs and other medical modalities would be done on behalf of security, discipline, or punishment" in the prison).

114. The bias may stem, for example, from the fact that the would-be GBMI inmate made an NGRI defense, or from the very fact of referral to the fact-finder for the current proceeding.

115. Under the LRA procedure, the fact-finder would have to misfind with respect to the currentneed standard, as compared to the official under the GBMI law who already has authorization to treat under the verdict. The former authority is constrained by a legal standard, however inadequate, while the latter may make discretionary treatment decisions. Further, in the LRA situation, although an NGRI defense was made, the jury rejected it; the record is officially silent on the question of the offender's mental status. 'Therefore, the fact-finder does not have the same pressure of the preexisting public record of mental illness. 


\section{State Interests}

The proposed alternative adequately protects the state interests that were found relevant to a due process analysis of GBMI laws.

\section{Protection of Persons}

The alternative protects prison populations and the community-atlarge.

\section{a. Protection of Persons in the Place of Incarceration}

The LRA procedure provides a reasonable level of security for persons in prison. It incorporates the existing mechanisms that both the prison's administrative authority ${ }^{116}$ and the civil police power give to the state for the orderly operation of the institutions and for the protection of persons. ${ }^{117}$

Use of the LRA procedure on the would-be GBMI inmates would place a minimal burden on the state. First, it is speculative whether would-be GBMI inmates actually would present a security problem. ${ }^{118}$ Further, there is a relatively small number of inmates in the class of NGRI claimants. ${ }^{119}$ Finally, prison inmates live in a highly controlled and monitored environment, so any developing problems could be identified readily.

\section{b. Post-release Protection of Persons in the Community}

Given that it is unlikely that compelled treatment of a prisoner's mental illness will have a long-term effect of reduced future criminality, ${ }^{120}$ the removal of the requirement of treatment would not meaningfully reduce post-release protection of the community. In fact, to the extent that treatment may be more effective when it is voluntary, ${ }^{121}$ the LRA actually may increase the probability of rehabilitation. Removing the power of

116. See supra note 37 (Coffin doctrine does not prohibit abridging rights if required for incarceration).

117. Therefore, existing state power either gives prisons control equal to or in excess of that given by a GBMI verdict, or the GBMI verdict grants control in excess of that which current law considers necessary to protect persons. In either case, the GBMI verdict is a redundancy with respect to the suggested rationale of protection of persons in prison.

118. See supra pp. $490-91$ (arguing that GBMI inmate may be no more dangerous than other inmates).

119. See H. Steadman, supra note 84 , at $2-3,7$ (insanity pleas "exceedingly infrequent" with estimate in one jurisdiction under $0.2 \%$ of felony cases).

120. See supra note 101 (discussing ephemeral nature of psychiatric therapies).

121. See, e.g., K. Heller \& J. Monahan, Psychology and Community Change 243 (1977) (behavioral techniques least effective for automatic conditioning and more effective when involving cooperation and active cognitive participation). 
compulsion from the state also creates an incentive for the state to make programs and therapies attractive to the inmates. ${ }^{122}$ Further, if prison authorities remove an inmate from a probably ineffective "treatment" regime, the inmate could direct more time and energy to other prison rehabilitation programs-such as education and skill development-that may better promote community protection. ${ }^{123}$

\section{Benefit to the GBMI Prisoner}

The LRA proposal adopts precisely the standard that society uses generally for the exercise of the state's parens patriae power. When benefit to the individual is separated from other state interests, there is no analytical difference between the situation of a prisoner and that of any other member of society.

\section{Efficiency of Prison Administration}

The LRA approach allows the prison to exercise its administrative authority in meeting the needs of the institution. The prison may allocate its resources on the basis of current need, rather than by statutory presumptions. This results in greater administrative flexibility and more rational resource allocation. It is unlikely that such current-need procedures would cost more than those mandated by GBMI laws. ${ }^{124}$ Even if they did, however, cost saving well may be an impermissible state interest in this context. $^{128}$

\section{Conclusion}

The guilty but mentally ill verdict is a popular response to longstanding and severe problems concerning mentally-ill criminal defendants. A jury's finding that mental illness existed at the time of the crime is the GBMI law's key to authorizing state imposition of psychiatric examinations and therapies upon the GBMI inmate. This power extends throughout the period of the criminal sentence.

122. This proposition rests on the assumption that the state believes that such programs and therapies rehabilitate.

123. See TheORIES OF PUNISHMENT 229-30 (S. Grupp ed. 1971). But see A. VON HiRSCH, DOING JUSTICE: THE CHOICE OF PUNISHMENTS (1976) (advocating rejection of rehabilitation as sentencing objective); Lopez, supra note 99, at 533 (same).

124. See supra p. 495 (requiring offer of care to all inmates who pursued NGRI defense unlikely to increase costs).

125. To the extent that the GBMI verdict threatens to violate fundamental rights, it should not be justified on the basis of administrative convenience or cost-saving for the state. The Supreme Court has rejected such a tradeoff. See Fuentes v. Shevin, 407 U.S. 67, 90 n.22 (1972) (in due process context, "Constitution recognizes higher values than speed and efficiency") (quoting Stanley v. Illinois, 405 U.S. 645,656 (1972)). 
Under a due process balancing test, GBMI procedures are inadequate to justify the losses to which a GBMI inmate is exposed. There are few, if any, state interests advanced by the GBMI verdict as compared to the traditional guilty verdict. When compared to a guilty verdict, the GBMI verdict implicates several constitutionally derived rights and interests. Further, the probability of erroneous deprivation of rights is high. A less restrictive alternative based on a finding of current need and including an offer of voluntary treatment to any inmate who made an insanity defense would reduce the chance of error, reduce losses to the individual, and protect the interests of the state as well as, or better than, the GBMI system. 